\title{
121. Q-Banding Analysis of Long Acrocentric Chromosomes in HeLa Cells newly Appeared after X-Irradiation
}

\author{
By Soichiro KoIwaI and Kihei Kubo \\ Department of Radiology, Sapporo Medical College, Sapporo 060 \\ (Communicated by Sajiro Makino, M. J. A., Dec. 12, 1980)
}

Considerable information has been available so far on the appearance of marker chromosomes in relation to radioresistance following irradiation (Rhynas and Newcombe 1960; Whitefield and Rixon 1961; Bhaskaran and Dittrich 1963). Muta and Koiwai (1970) have established several radioresistant strains in HeLa-cell populations after repeated X-irradiations. The cells of these strains have been characterized by containing unusually long acrocentric markers (LA) (Koiwai and Muta 1974). In the long term cultivation of one of such strains, its radioresistant activity was deleted without loss of the LA chromosomes (Koiwai et al. 1979). The evidence presented seems to indicate that the LA chromosomes have not directly been associated with the radioresistance of this strain. On the other hand, Kubo et al. (1978) reported the chromosomes of a morphologically similar nature which appeared spontaneously in the resistant cells without irradiation. Thus, the fact showing that all the radioresistant strain cells so far obtained by us contained without exception such LA elements may be an indication that they serve as an index of radioresistance of cells.

Under the above status, it is highly needed to analyse the structure and origin of those LA chromosomes occurring in the radiationtreated cells with the application of current technical procedures, referring to radioresistance. In this paper are presented the results of the quinacrine-banding $(\mathrm{Q})$ analysis of the LA chromosomes.

Materials and methods. HeLa cells from a population SC established by Koiwai and Muta (1974) were grown as monolayer in Eagle's minimum essential medium, supplemented with $10 \%$ fetal bovine serum at $37^{\circ} \mathrm{C}$ in a humidified atmosphere of $95 \%$ air and $5 \% \mathrm{CO}_{2}$. Cells were plated after trypsinization in a plastic Petri dish (Falcon 3002 ) at the concentration of $5 \times 10^{4}$ cells/dish. After $24 \mathrm{hr}$, the dishes were X-irradiated with 800 rad. X-irradiation was carried out with a Toshiba KXC-18 X-ray source operating at $200 \mathrm{kVp}$ and $25 \mathrm{~mA}$ with $0.3 \mathrm{~mm} \mathrm{Cu}$ and $0.5 \mathrm{~mm} \mathrm{Al}$ filters, at the mean dose rate of $196 \mathrm{rad} / \mathrm{min}$. On 6 days after irradiation, the medium was replaced with fresh one. Subcultures were made on 10 days and 14 days after irradiation. On 
the 16th or 17th day of cultivation, the cells were subjected to colcemid for one hour at a final concentration of $0.05 \mu \mathrm{g} / \mathrm{ml}$. Cells were then harvested through trypsinization, treated with the hypotonic solution $(0.075 \mathrm{M} \mathrm{KCl})$ for $20 \mathrm{~min}$, and fixed with methanol-acetic acid $(3: 1)$. Cells suspended in the fixative were dropped onto slides and air-dried. Slides thus prepared were stained with Giemsa solution and quinacrine mustard-Hoechist solution (Yoshida et al. 1975). Control chromosome preparations were made by the same procedure as mentioned above without X-ray treatment. Each experiment was repeated three times.

Results and remarks. The incidence of cells containing unusually long acrocentric chromosomes (LA markers) in the non-treated and $\mathrm{X}$-irradiated populations was presented in Table I. The incidence of cells with LA markers (LA (+) cells) was $2.6 \%$ in the control nontreated cells. The previous study indicated that the mean lethal dose

Table I. Frequencies of cells with unusually long acrocentric chromosomes (LA(+) cells) in the untreated and $\mathrm{X}$-irradiated populations

\begin{tabular}{cccc}
\hline \multirow{2}{*}{ Cells examined } & \multirow{2}{*}{ Control } & \multicolumn{2}{c}{ X-irradiated } \\
\cline { 3 - 4 } & & Expected & Observed \\
\hline Total no. of cells & 841 & - & 353 \\
No. of LA $(+)$ cells & 22 & - & 99 \\
\hline$\%$ & 2.6 & 11.1 & 28 \\
\hline
\end{tabular}

$\left(D_{0}\right)$ value was determined as $160 \mathrm{rad}$ for the control population, while the values for several radioresistant strains distributed around $220 \mathrm{rad}$ (Kubo et al. 1980). If the $\mathrm{D}_{0}$ values of all the LA $(+)$ cells in the control population would distribute around $220 \mathrm{rad}$, the incidence of the LA markers might be expected as $11.1 \%$ in cells irradiated with $800 \mathrm{rad}$, as shown in Table I. The observed value which was shown as $28 \%$, however, was much higher than the expected one. This result seems to suggest that the radiation-induced LA markers cover a considerable part of all the LA markers occurring in the irradiated population. Thus, it seems important to analyse the nature of the LA markers with the Q-banding method in relation to their origin.

In the first place, the Q-banding karyotype was analysed in a dozen of the non-treated cells in the SC population. The results are summarized in Table II. Cells under study contained 44 to 51 intact human chromosomes in addition to 14 to 21 marker chromosomes. There were 28 types of marker chromosomes of different origin in this population. The marker chromosomes, $\mathrm{m} \mathrm{1,} \mathrm{m} \mathrm{2,} \mathrm{m} 3$ and $\mathrm{m} \mathrm{9,}$ 
occurred in all the karyotypes here dealt with. Most cells contained markers, $\mathrm{m}$ 4-6, $\mathrm{m} \mathrm{10,} \mathrm{m} \mathrm{11,} \mathrm{m} \mathrm{16,} \mathrm{m} 18$ and $\mathrm{m} \mathrm{21.} \mathrm{Chromosomes}$ similar in appearance to $\mathrm{m} 3$ and $\mathrm{m} 10$ were reported to occur in

Table II. Different types of marker chromosomes and their frequencies in twelve HeLa cells observed

\begin{tabular}{|c|c|c|}
\hline $\begin{array}{l}\text { Marker } \\
\text { no. }\end{array}$ & $\begin{array}{l}\text { No. of } \\
\text { cells } \\
\text { studied }\end{array}$ & Possible origin \\
\hline 1 & 12 & $\mathrm{t}(1 ; 2)(1 \mathrm{pter} \rightarrow 1 \mathrm{q} 42:: 2 q 31 \rightarrow 2 q$ ter $)$ \\
\hline 2 & 12 & $\mathrm{t}(1 ; 3 ; 7)(1 \mathrm{q} 32 \rightarrow 1$ cen $:: 3 q 12 \rightarrow 3 \mathrm{q} 27:: 7 \mathrm{q} 22 \rightarrow 7$ qter $)$ \\
\hline 3 & 12 & $\mathrm{t}(1 ; 3)(1$ qter $\rightarrow 1$ cen $:: 3$ cen $\rightarrow 3$ qter $)$ \\
\hline 4 & 10 & $\mathrm{t}(3 ; 6)(3$ pter $\rightarrow 3$ cen $:: 6$ cen $\rightarrow 6 \mathrm{q} 23)$ \\
\hline 5 & 11 & $\mathrm{t}(2 ; 8)(2 \mathrm{p} 23 \rightarrow 2$ cen $:: 8$ cen $\rightarrow 8 \mathrm{qter})$ \\
\hline 6 & 11 & $\mathrm{t}(4 ; 10)(4$ pter $\rightarrow 4$ cen $:: 10$ cen $\rightarrow 10$ q24) \\
\hline 7 & 4 & $\operatorname{del}(4)($ pter $\rightarrow$ q25) \\
\hline 8 & 8 & $\mathrm{t}(17 ; 18)(17$ pter $\rightarrow 17$ cen $:: 18$ cen $\rightarrow 18$ qter $)$ \\
\hline 9 & 12 & $\mathrm{i}(8)($ pter $\rightarrow$ cen $\rightarrow$ pter $)$ \\
\hline 10 & 11 & $\mathrm{i}(5)($ pter $\rightarrow$ cen $\rightarrow$ pter $)$ \\
\hline 11 & 11 & $\mathrm{i}(11)(\mathrm{pter} \rightarrow$ cen $\rightarrow$ pter $)$ \\
\hline 12 & 2 & $\mathrm{i}(16)($ pter $\rightarrow$ cen $\rightarrow$ pter $)$ \\
\hline 13 & 5 & $\begin{array}{l}\mathrm{t}(9 ; 2 ; 10 ; 3)(9 \mathrm{qter} \rightarrow 9 \mathrm{q} 13:: 2 \mathrm{p} 13 \rightarrow 2 \mathrm{cen}:: 10 \mathrm{cen} \\
\quad \rightarrow 10 \mathrm{q} 24:: 3 \mathrm{p} 13 \rightarrow 3 \mathrm{pter})\end{array}$ \\
\hline 14 & 9 & $\mathrm{t}(5 ; 8)(8 \mathrm{pter} \rightarrow 8 \mathrm{q} 24:: 5 \mathrm{q} 31 \rightarrow 5 \mathrm{qter})$ \\
\hline 15 & 9 & $\mathrm{t}(8 ; 12)(12$ pter $\rightarrow 12 q 13:: 8 q 12 \rightarrow 8 q$ ter $)$ \\
\hline 16 & 10 & $\mathrm{t}(7 ; ?)(7 \mathrm{pter} \rightarrow 7 \mathrm{q} 36:: ?)$ \\
\hline 17 & 1 & $\mathrm{t}(13 ; 16)(16 \mathrm{pter} \rightarrow 16 \mathrm{q} 13:: 13 \mathrm{q} 12 \rightarrow 13 q$ ter $)$ \\
\hline 18 & 10 & $\mathrm{t}(12 ; 19)(19$ qter $\rightarrow 19$ cen $:: 12 q 13 \rightarrow 12$ qter $)$ \\
\hline 19 & 2 & $\operatorname{del}(9)($ pter $\rightarrow$ q22) \\
\hline 20 & 8 & $\operatorname{del}(3)(\mathrm{pter} \rightarrow \mathrm{q} 11)$ \\
\hline 21 & 10 & $\mathrm{t}(22 ; ?)(22$ pter $\rightarrow 22 q 13:: ?)$ \\
\hline 22 & 4 & $\mathrm{t}(3 ; 7)(7 \mathrm{pter} \rightarrow 7 \mathrm{q} 32:: 3 \mathrm{p} 13 \rightarrow 3$ pter $)$ \\
\hline 23 & 1 & $\operatorname{del}(1)(p$ ter $\rightarrow q 25)$ \\
\hline 24 & 2 & $\mathrm{t}(3 ; 5)(5 \mathrm{pter} \rightarrow 5 \mathrm{q} 12:: 3 \mathrm{q} 13 \rightarrow 3 \mathrm{qter})$ \\
\hline 25 & 3 & $\mathrm{t}(2 ; 10 ; 3)(2 \mathrm{p} 13 \rightarrow 2$ cen $:: 10$ cen $\rightarrow 10 \mathrm{q} 24:: 3 \mathrm{q} 13 \rightarrow 3$ pter $)$ \\
\hline 26 & 6 & $\operatorname{del}(5)(p t e r \rightarrow q 31)$ \\
\hline 27 & 1 & $\operatorname{del}(4)($ pter $\rightarrow$ q25) \\
\hline 28 & 4 & $\mathrm{t}(4 ; 12)(12$ pter $\rightarrow 12$ cen $:: 4$ cen $\rightarrow$ 4qter $)$ \\
\hline
\end{tabular}

HeLa cells by Hennen (1976) and Rin and Goldstein (1974). Fig. 1 shows a Q-banding karyotype in one of the non-treated cells from the SC population (Fig. 1A). Some other cells of the same population contained additional markers as shown in Fig. 1B.

In cells received $800 \mathrm{rad}, 95$ cells with the LA markers were karyotypically analysed. Fig. 2 illustrates five types of the LA chromosomes structurally different which were observed in those LA (+) cells. LA 1 seems to be recognized in origin as the marker, $\mathrm{m} 13$ or $\mathrm{m} 25$, occurring in the non-treated karyotype. The origin of 
LA 2 may be the long arm of $m 2$. The possible origin of the five types of the LA chromosomes is shown in Table III, together with their frequencies obtained in the ninety-five karyotypes. The incidences of LA 1 and LA 2 were $83.1 \%$ and $11.6 \%$, respectively, observed in LA $(+)$ cells. LA 3, LA 4 and LA 5 were seen each in a single LA (+) cell. The above evidence suggests that the LA markers are not of single origin, although considered so in the former paper (Koiwai and Muta 1974), but of multiple origin, particularly in relation to at least

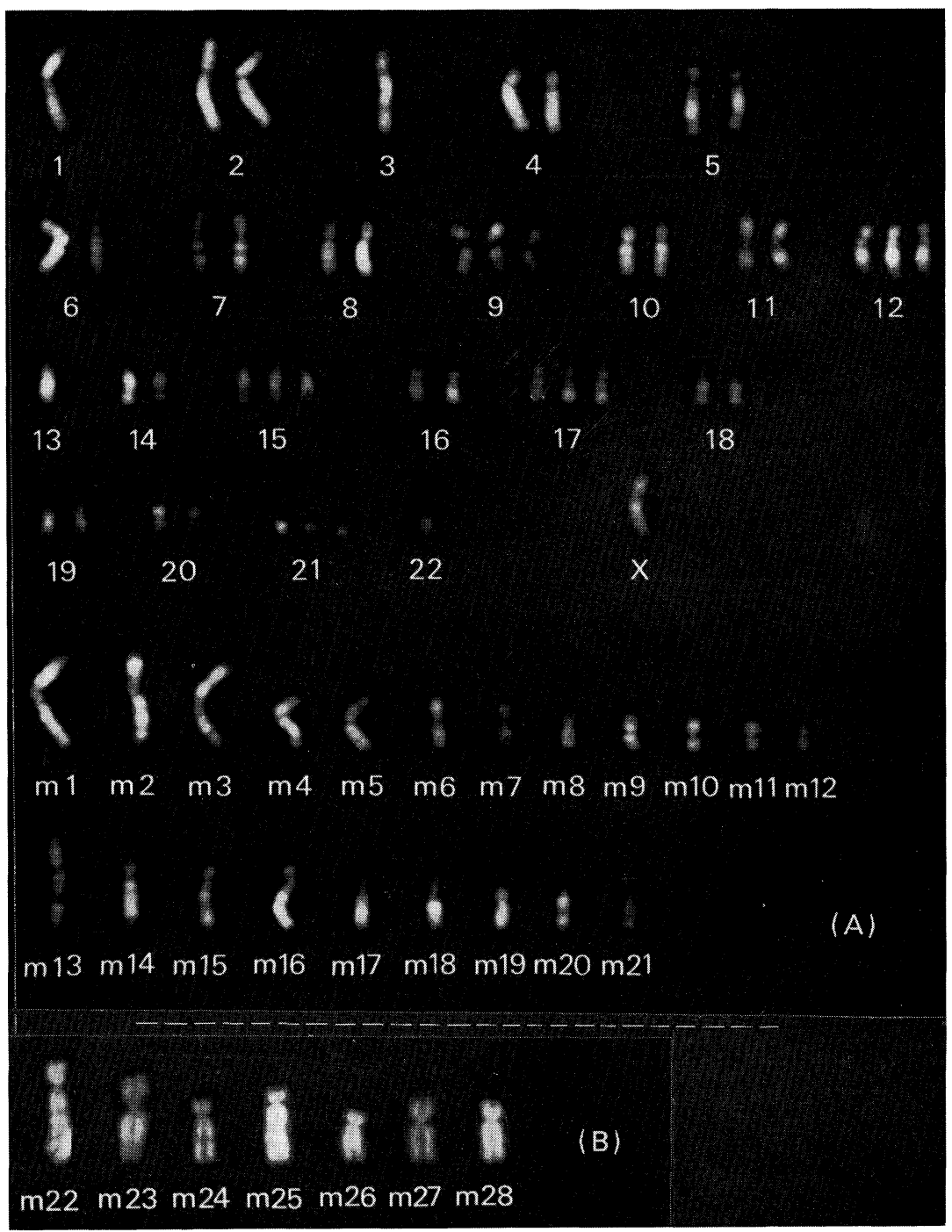

Fig. 1. Q-banded chromosomes in HeLa cells. A: Q-banding karyotype of a cell (SC-population) consisting of 46 intact chromosomes with 21 marker chromosomes. B: 7 additional markers occurring in other cells. 
5 structurally different markers. The above features allow the following conclusion that the LA chromosomes do not always serve as the index of the radioresistance. Thus, it appeared that all the strains containing the LA chromosomes are not always radioresistant, since there are cells containing LA chromosomes which do not deal with radioresistance. The investigations of the five LA chromosomes in relation to radioresistance have been in progress.

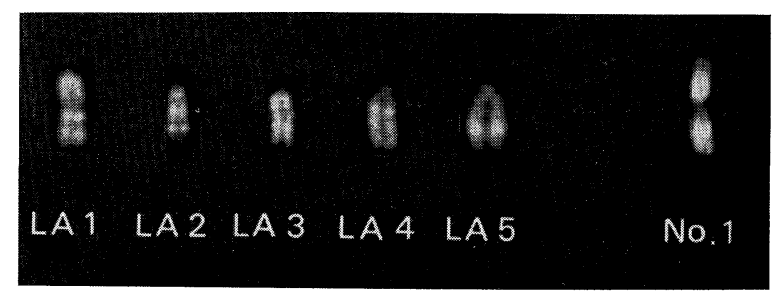

Fig. 2. 5 Q-banded unusually long acrocentric chromosomes (LA 1-5) observed in the X-irradiated cells, and normal no. 1 chromosome (No. 1) for comparison.

Table III. Different types of unusually long acrocentric chromosomes observed in the irradiated HeLa-cell population and their

frequencies in ninety-five cells

\begin{tabular}{ccl}
\hline $\begin{array}{c}\text { LA } \\
\text { marker }\end{array}$ & $\begin{array}{c}\text { No. of } \\
\text { cells } \\
\text { observed }\end{array}$ & \multicolumn{1}{c}{ Possible origin } \\
\hline LA1 & 87 & $\mathrm{t}(3 ; 10)(10 \mathrm{cen} \rightarrow 10 \mathrm{q} 24:: 3 \mathrm{p} 13 \rightarrow 3 \mathrm{pter})$ \\
LA2 & 11 & $\mathrm{t}(3 ; 7)(3 \mathrm{q} 12 \rightarrow 3 \mathrm{q} 27:: 7 \mathrm{q} 22 \rightarrow 7 \mathrm{q}$ ter $)$ \\
LA3 & 1 & $\mathrm{t}(? ; 2)(?:: 2 \mathrm{q} 23 \rightarrow 2 \mathrm{qter})$ \\
LA4 & 1 & $\mathrm{t}(13 ; 1 ; 2)(13 \mathrm{pter} \rightarrow 13 \mathrm{q} 14:: 1 \mathrm{q} 25 \rightarrow 1 \mathrm{q} 42:: 2 \mathrm{q} 31 \rightarrow 2 \mathrm{qter})$ \\
LA5 & 1 & $\mathrm{t}(? ; 12)(?:: 12 \mathrm{q} 13 \rightarrow 12 \mathrm{qter})$
\end{tabular}

Summary. The nature and origin of unusually long acrocentric marker chromosomes were investigated in relation to radioresistance with the application of the Q-banding method. In cells receiving $800 \mathrm{rad}$, there were five types of unusually long acrocentric markers, different in structure. Evidence presented seems to suggest that all the strains with the LA markers are not always radioresistant.

Acknowledgements. The authors are deeply indebted to Emeritus Professor Sajiro Makino, M. J. A., for his critical reading. Also they thank Professor Motomichi Sasaki and Dr. Michihiro C. Yoshida, Chromosome Research Unit, Hokkaido University, for their valuable advice. Supported in part by a grant from the Hokkaido Government. 


\section{References}

Bhaskaran, S., and Dittrich, W. (1963) : Strahlentherapie, 122, 270-278.

Heneen, W. K. (1976) : Hereditas, 82, 217-248.

Koiwai, S., and Muta, N. (1974) : Radiat. Res., 59, 717-723.

Koiwai, S., Kubo, K., and Muta, N. (1979) : J. Radiat. Res., 20, 34.

Kubo, K., Koiwai, S., and Muta, N. (1978): J. Radiat. Res., 19, 55. (1980) : J. Radiat. Res., 21, 18.

Lin, C. C., and Goldstein, S. (1974) : J. Natl. Cancer Inst., 53, 298-304.

Muta, N., and Koiwai, S. (1970) : Radiat. Res., 43, 332-340.

Rhynas, P. O. W., and Newcombe, H. B. (1960) : Exptl. Cell Res., 21, 326-331.

Whitefield, J. F., and Rixon, R. H. (1961): Exptl. Cell Res., 23, 412-415.

Yoshida, M. C., Ikeuchi, T., and Sasaki, M. (1975) : Proc. Japan Acad., 51, 184187. 